\title{
Transmission and Transformation of the Eusebian Gospel Apparatus in Greek Medieval Manuscripts
}

\begin{abstract}
Scholars have often assumed that the Eusebian apparatus was defunct and ignored in the Middle Ages. I argue, however, that Greek manuscripts offer evidence for readers' ongoing use of the Eusebian apparatus. While the transmission of the Eusebian apparatus was subject to error, users maintained the functionality of the Eusebian system. Readers adapted the apparatus in order to make it a better resource for their reading of the gospels. Transformations of the Eusebian system are part of its reception history, illuminating how readers used Eusebius's project. They demonstrate both the continued vitality of the apparatus and medieval readers' vibrant interest in comparative studies of the gospels.
\end{abstract}

\section{Introduction}

Writing in 1904, New Testament scholar Adolf Jülicher described Eusebius of Caesarea's (c. 260-339 CE) system of gospel canons and sections as 'too complicated to be handed on without corruption', and able to be 'vitiated' by a 'few mistakes'. ${ }^{1}$ According to Jülicher, the Eusebian apparatus was already an anachronism well before the second millennium. While it was copied-and more often miscopied-by later scribes, it was neither used nor understood, for 'all interest', Jülicher says, 'in these comparative studies had long died out'. Jülicher brings into focus the question I address in this chapter: Was the Eusebian system of canons and sections useful in the Middle Ages?

Recent scholarship has engaged the late ancient reception of the Eusebian apparatus. In Late Antiquity, the apparatus was extensively translated, appearing in (at least) Latin, Syriac, Gothic, Armenian, Georgian, Caucasian Albanian, and Ethiopic. ${ }^{2}$ This reception is illustrated by the Garima Gospels and Codex Fuldensis (546 CE). ${ }^{3}$

\footnotetext{
1 Jülicher 1904, 587-88.

2 On these translations, see Nordenfalk 1938 (for Greek, Latin, Syriac, and Gothic); cf. Nestle 1908; Oliver 1959, 140-43; McArthur 1965, 165. 3 On the Garima Gospels (including the question of date), see Bausi 2011; McKenzie/Watson 2016; on the Ethiopic Eusebian apparatus, see Grébaut 1913; Leroy 1962; Mercier 2000; Bausi 2002; Bausi 2015. On the Eusebian apparatus and Codex Fuldensis, see Crawford in this volume, as well as Nestle 1908; de Bruyne 1927; McGurk 1955; Petersen 1994, 45-50; Houghton 2016, 56-58. Augustine's use of the Eusebian apparatus (see note 20 below) is also a late ancient
}

Moreover, late ancient readers adapted the Eusebian apparatus. To mention two examples, Eusebius's invention was expanded to include the longer ending of Mark (16:9-20) and was expanded for its inclusion in the Syriac Peshițta Gospels. ${ }^{4}$ Yet while scholars have observed the ways that the Eusebian apparatus continued to be used and adapted in Late Antiquity, Jülicher's assumptions must still be challenged when it comes to medieval manuscripts. Even eighty years after Carl Nordenfalk's work on the Eusebian canons, Jülicher's perspective often characterizes approaches to the Eusebian apparatus. Others over the past century have described the apparatus as impossibly difficult to transmit and, in any case, as 'primitive', waiting to be 'superseded' by modern columnar synopses of the gospels. ${ }^{5}$ Discussions of the Eusebian apparatus emphasize its intricacy in order to justify its ostensibly non-functional manuscript transmission.

Over the past few decades, scholars of early Christianity have developed a renewed appreciation for the intellectual vitality of Byzantium and of the Middle Ages more broadly. In line with these insights, I here challenge the idea that the Eusebian apparatus in medieval manuscripts was defunct and ignored. To make this argument, I focus on Greek manuscripts with the Eusebian apparatus. The preserved evidence is rich in both quantity and variety. As a result, I have been selective, focusing on a handful of

phenomenon. One might likewise consider the Hiberno-Latin reception of the Eusebian apparatus as a late ancient phenomenon; see Mullins in this volume and McGurk 1955; McGurk 1993; Howlett 1996, 12-20; O’Loughlin 1999; Howlett 2001; Mullins 2001; Beall 2005; O'Loughlin 2007; O'Loughlin 2009; Howlett 2010; O'Loughlin 2010; Mullins 2014; Crawford 2017; O’Loughlin 2017a; O’Loughlin 2017b; Crawford 2019, 195-227.

4 On the Eusebian apparatus and the longer Markan ending, see (inter alia) Burgon 1871, 125-32; Scrivener 1894, 2:337-344; Gregory 1900, 869-72; von Soden 1902, 394-96; McArthur 1965, 250n4; Kelhoffer 2001; Zamagni 2016, 230-32; Knust and Wasserman 2018, 193-95. Many other discussions of the longer ending mention the Eusebian apparatus briefly. On the Eusebian apparatus in the Peshițta, see Burgon 1871, 308-12; Hall 1882, 141; Gwilliam 1890; Baumstark 1901; Nestle 1908; Nordenfalk 1938, 221-60; Vaccari 1957; Engelbrecht 1994, 148; Crawford 2019, 156-194.

5 McArthur 1965, 254, 256. Cf. Oliver 1959, 138 ('an inadequate critical tool'). For dismissive claims before Jülicher, see von Soden 1902, 392 and Burgon 1871, 301 (a 'clumsy substitute' for modern reference tools). There are exceptions: Nestle 1908 shares none of Jülicher's pessimism. 
textual phenomena which are paralleled in the transmission of the Eusebian apparatus in other languages. ${ }^{6}$

First, I consider manuscript transmission. ${ }^{7}$ As one would expect with any manuscript phenomenon, haphazard copying affects the Eusebian apparatus in medieval manuscriptsacrosslanguages. Many copies of theEusebian apparatus are flawed, some spectacularly so. But in other manuscripts, the transmission of the apparatus is surprisingly accurate. The Eusebian apparatus was not 'vitiated', as Jülicher claimed; instead, users maintained the functionality of the Eusebian system.

Second, I demonstrate that medieval readers transformed the Eusebian apparatus for their own ends. Tracing histories of reading is difficult, since, as Roger Chartier argues, reading 'only rarely leaves traces [...] scattered in an infinity of singular acts' ${ }^{8}$ Nonetheless, medieval readers left evidence of their use of the Eusebian apparatus both in appropriation for exegetical compositions and in reconfigurations of the Eusebian system. Modifications of the Eusebian system are part of its reception history, illuminating how readers understood and used Eusebius's project. ${ }^{9}$ As a result, I argue, these modifications demonstrate both the continued vitality of the apparatus and medieval readers' vibrant interest in 'comparative studies' of the gospels. ${ }^{10}$

\section{Transmission}

Numbers are among the most easily corrupted features in any manuscript tradition. A fortiori, we would expect a large group of numbers like the Eusebian apparatus to exhibit errors when copied. While we lack an editio critica maior for the Eusebian apparatus, it is clear that most sets of canons include at least a handful of mistakes. ${ }^{11}$

6 While visual aspects of the Eusebian apparatus are significant, here I focus on the apparatus as a textual system. Previous studies of the apparatus as a textual system include Nestle 1908; Barber Thiele 1981; Nordenfalk 1984; McGurk 1993; Crawford 2019; they were not the focus of Nordenfalk's 1938 study.

7 See the forthcoming editio minor of Martin Wallraff and Patrick Andrist (2021), which focuses on first-millennium evidence.

8 Chartier 1994, 1-2.

9 Here I apply the conceptual framework of Rezeptionsgeschichte articulated by Jauss 1970; cf. Evans 2014. My approach builds on Breed 2014, as well as recent discussions in classical reception, especially Hardwick/Stray 2008; Butler 2016; Kraus/Stray 2016; Hunt et al. 2017, 85-148.

10 Pace Jülicher 1904, 588.

11 The following arguments about the transmission of the Eusebian apparatus are based on my ongoing research involving extensive manuscript evidence in Greek, Syriac, Latin, and Ethiopic. Statistical
Section and canon numbers in the margins are likewise subject to error. They drift up and down in relation to the text and the numbers themselves are sometimes copied incorrectly. But was the apparatus 'too complicated to be handed on without corruption' and thus made irrelevant by a 'few mistakes', as Jülicher claimed ${ }^{12}$ This, I argue, is simply not the case. Despite infelicities of transmission, the Eusebian apparatus continued to be copied, used, and adapted throughout the Middle Ages.

As a case study, I examine Eusebius's canon IX in a number of Greek manuscripts. Canon IX correlates parallel material shared by Luke and John. It is one of the shorter canons, with a mere twenty-one parallels. Yet this canon is complicated on both textual and exegetical levels. While there are twenty-one parallels, this does not mean there are twenty-one passages in each column. Rather, both Luke and John columns duplicate passages in order to create a rich matrix of interconnections between the two gospel narratives. Most notably, in the case of Pilate's declarations of Jesus' innocence three sections in Luke $(\S \S 303,307,312)$ are each juxtaposed with three other sections in John $(\S \S 182,186,190)$. The result is a total of nine parallels constructed from three passages in each gospel. Of the twenty-one parallels in canon IX, not a single one simply juxtaposes one passage in Luke with one passage in John. In canon IX, the probability of error increases because most numbers occur multiple times in each column.

Some manuscripts present a text of the Eusebian apparatus that is dodgy at best. For a particularly flawed example, consider the thirteenth-century Paris, Bibliothèque nationale de France, MS grec 91 (GA 10) (Fig. 1). As is immediately visible at the bottom of canon IX, something has gone wrong. The sets of three identical section numbers seem to have thrown off the scribe. In the Luke column, moreover, the number $\overline{\tau \zeta}$ (\$307) is missing twice. In addition, four numbers are inadvertently juxtaposed with three at one point. After all these mistakes, the canon exhibits a 'cascading error' through which all subsequent parallels are misaligned. The result of these nonsense errors is a disaster: three sections at the end of the John column lack any parallels in Luke at all. (In addi-

measures of the accuracy with which the Eusebian apparatus was transmitted are not available. Studies of the Eusebian apparatus in individual late ancient manuscripts (Codex Sinaiticus [GA 01]: Jongkind 2007, 109-20; Codex Alexandrinus [GA 02]: Smith 2014, 333-46; GA 022, 023, 042: Hixson 2019) offer preliminary indications. Von Soden $(1902,392)$ estimates that approximately one quarter of gospel manuscripts with the Eusebian apparatus have the wrong number of sections in at least one gospel.

12 Jülicher 1904, 587. 


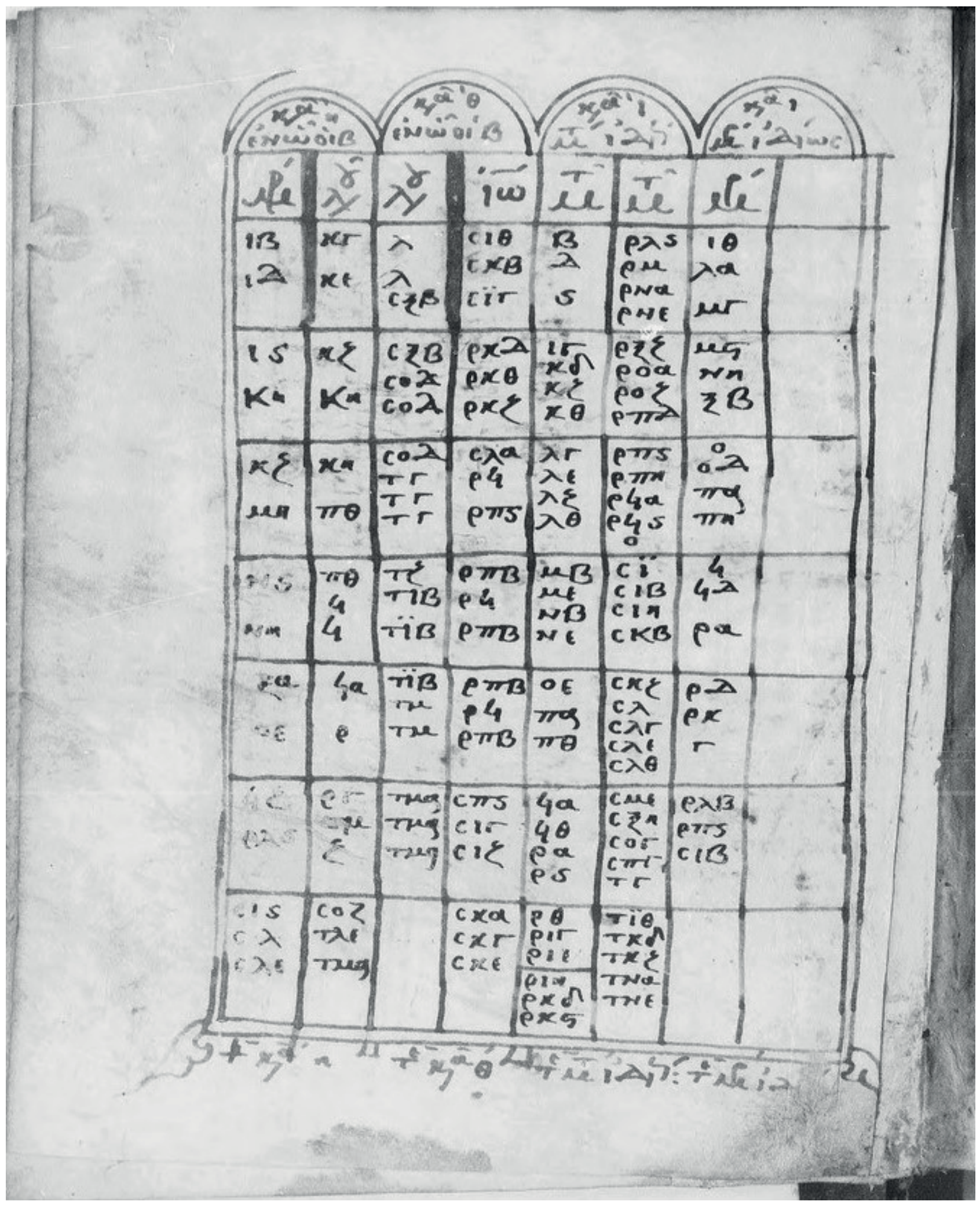

Fig. 1: Paris, Bibliothèque nationale de France, MS grec 91, fol. 4v: Canons VIII, IX, X (Matthew), and X (Mark). Source gallica.bnf.fr / BnF. 


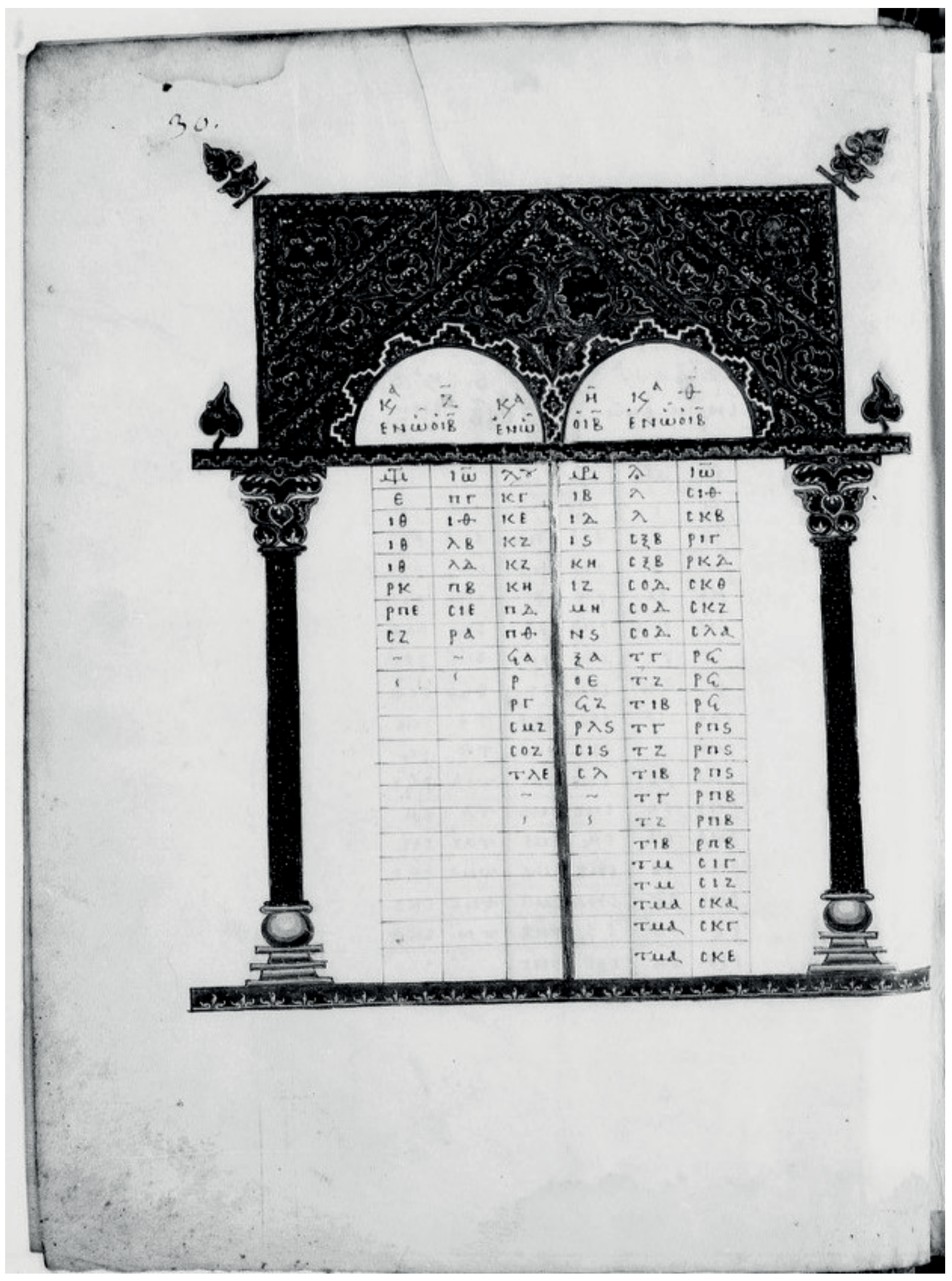

Fig. 2: Paris, Bibliothèque nationale de France, MS grec 230, p. 30: Canons VII, VIII, and IX. Source gallica.bnf.fr / BnF. 
tion, there are a number of graphic errors, for example, confusing rho and sigma to create impossible 'numbers'.) It is hard to fathom that the scribe did not notice these glaring problems, but he or she did not correct them. ${ }^{13}$ Of the parallels, only three of the twenty-one are arguably coherent. The other canons in this manuscript exhibit similar problems.

Nonetheless, this manuscript is unusual. Indeed, in some manuscripts, all the parallels are intact. Consider the fourteenth-century Paris, Bibliothèque nationale de France, MS grec 230 (GA 12) where canon IX is copied flawlessly (Fig. 2) ${ }^{14}$ Not only is the manuscript quite legible, but-with one caveat that I will discuss shortly-it transmits the Eusebian apparatus accurately. The apparatus could thus be transmitted with great fidelity even in the late Middle Ages.

Manuscripts of the Eusebian apparatus tend to fit somewhere between these two extremes. Most are problematic occasionally; few are persistently misleading. ${ }^{15}$ As an analogy to the Eusebian apparatus in medieval manuscripts, one might think of the modern internet. All users of the internet occasionally encounter bad hyperlinks, but no one would abandon the internet for this reason. Likewise, medieval users of the Eusebian apparatus apparently found that its value outweighed the frustration of occasional bad links. An ordinarily flawed copy of the apparatus is still possible to use. ${ }^{16}$

To put the transmission of the Eusebian apparatus in a different light, we might consider the work of another ancient scholar who created a much-copied and muchused system of tables. Here I refer to Claudius Ptolemy, the second-century CE mathematician and astronomer. As an ancient tool for organizing knowledge, Ptolemy's

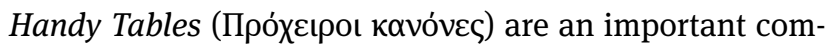
parandum for the origins and early use of the Eusebian apparatus. ${ }^{17}$ The value of comparison is not limited to the

13 There are other cases in which there was apparently no effort to present a useable apparatus. The eighth-century CE Latin Lindisfarne Gospels (London, British Library, Cotton MS Nero D.IV; cf. McGurk 1955; Houghton 2016, 279; O'Loughlin 2017b; Watson 2017) and the sixth- or seventh-century CE Greek Golden canon tables (London, British Library, Add. MS 5111/1) are well-known examples.

14 Cf. the twelfth-century Paris, Bibliothèque nationale de France, MS grec 64 (GA 15), fol. $7 \mathrm{v}$.

15 Error is not limited to manuscripts, printed editions are sometimes inaccurate (Nestle 1908; Wallraff 2016).

16 The apparatus is expensive and time-consuming to produce. If indeed the apparatus was not used, it seems implausible that its artistic and metaphorical value alone would justify its transmission. I am grateful to Garrick Allen for this point.

17 Like Eusebius, Ptolemy employed tables in a number of works, but here I focus on the Handy Tables. On the Handy Tables and their late ancient origins of these two sets of tables, however; it extends to how they were transmitted. Like Eusebius's apparatus, Ptolemy's work consists of tables of numbers, although in Ptolemy's case they contain dates, coordinates, and declinations, rather than numbers representing gospel passages. Both sets of tables were translated into a number of languages in Late Antiquity. Both circulated widely in numerous manuscripts and were sometimes modified for new contexts. As with the Eusebian apparatus, sometimes the copying of the Handy Tables went well and sometimes it did not. Both systems are intricate and difficult to copy, Ptolemy's perhaps even more than Eusebius's. Both are onerous to correct. Both are, moreover, impossible to reconstruct perfectly without an exemplar. Eusebius's system contains a number of creative juxtapositions, exegetical decisions that are not immediately obvious. Ptolemy's tables contain historical observational data that cannot be easily extrapolated. The systems are not self-correcting. If Eusebius's system is so complicated as to be useless after copying, then one would expect the same to have been true in the case of Ptolemy's Handy Tables. And, as one would expect, Ptolemy's system was often miscopied; no extant manuscript is free from error. Yet this did not vitiate the whole. As Otto Neugebauer has demonstrated in his monumental study of ancient mathematical astronomy, Ptolemy's tables-often changed and adapted-formed the computational basis for geography and astronomical prediction for almost fifteen hundred years. ${ }^{18}$ Ptolemy's Handy Tables continued to function, despite the infelicities that result from copying.

In a manuscript culture, readers grow accustomed to the reality that hand-copied texts include mistakes. This does not lead to abandoning those texts, however, but to correcting and improving them. As I have demonstrated, the Eusebian apparatus is sometimes transmitted in astonishingly good condition with only insignificant errors. The fact that the apparatus is often well-preserved offers invisible evidence for correcting. One would expect to find errors as a result of normal copying-and, indeed, manuscripts like Bibliothèque nationale de France, MS grec 91 (Fig. 1) confirm the need for correction. It is implausible that twelfth- and thirteenth-, and even fourteenth- and fifteenth-century, exemplars would reproduce a working form of a fourth-century paratextual

relationship to the Eusebian apparatus, see Nordenfalk 1982, 33; Mansfeld/Runia 1997, 111-116; Crawford 2019, 43-53.

18 On the widespread reception of Ptolemy's Handy Tables, see Neugebauer 1975, II, 969-1028. The first installment of a critical edition is now available (Tihon/Mercier 2011). Tihon's comments on the challenges of editing a 'reference work' apply equally to the Eusebian apparatus (Tihon/Mercier 2011, 5). 
system unless they were corrected along the way. Explicit evidence for such correction is offered by a certain Theophanes in a short text, preserved in a fourteenth-century gospel manuscript, that describes the process of correcting. ${ }^{19}$ Correction indicates that those who transmitted the Eusebian apparatus thought it was worth preserving as a text and not only as a decorative feature.

The dynamic of error and correction changes the Eusebian apparatus. In some cases, instead of collating from an exemplar, correctors revised the Eusebian apparatus based on their own theories of gospel relationships (indeed, this is precisely Theophanes' complaint). In other words, 'corrections' might not always yield the results toward which modern editors aspire. 'Correction' and 'modification' blur with one another. Nonetheless, both preserved a functional instrumentum for reading the gospels.

\section{Transformation}

Modifications of the Eusebian apparatus form a continuum. A reader or scribe might correct a nonsense reading, revise an apparently problematic set of parallels, or modify the structure of the Eusebian system as a whole. Each of these phenomena falls within the editorial remit of someone who transmits the Eusebian apparatus as a system for reading the gospels. The process of correcting ostensibly reverses errors, but often introduces new insights and interpretations into the Eusebian apparatus; no sharp line divides 'correction' from other kinds of change.

In the following pages, I discuss varieties of change as ways to observe the Eusebian apparatus at work. While refinements and modifications took place in Late Antiquity, I focus on changes that appeared between roughly 1000 and 1500 CE. It remains a difficult question when many innovations first occurred, since manuscripts generally afford only a terminus ante quem. Some phenomena occurred already in Late Antiquity, while others are attested only much later. A number of representative cases demonstrate what the Eusebian apparatus could do and what readers wanted to do with it. These histories of change illuminate how readers approached the Eusebian apparatus and, through it, the gospels.

19 Athens, National Library of Greece, cod. 92 (GA 1410), fols 7b-8b. The text is discussed by von Soden 1902, 392-393; Crawford 2019, 314-315.
Change sometimes occurred through omission. Omission could occur haphazardly as a result of incautious copying. Often, this involved omitting a row or skipping a number. (The discussion of Bibliothèque nationale de France, MS grec 91 above offered examples.) In some cases, artistic arrangement trumped other concerns. For example, in the tenth-century Paris, Bibliothèque nationale de France, MS grec 177 (GA 299), canon II (that is, Matthew, Mark, and Luke) was longer than the number of columns allottedand so the final column of Luke was simply left out in order to preserve the artistic presentation (Fig. 3).

Omissions sometimes went beyond these mishaps, revealing how readers used the Eusebian apparatus to access the gospels. Consider, for example, the twelfthcentury Vienna, Österreichische Nationalbibliothek, Suppl. gr. 52 (GA 3). In this manuscript, the canons end at canon IX on fol. 9v; Eusebius's canon X, which lists material unique to each of the four gospels, was not included. This omission is not the result of manuscript damage, however; it was intended in the layout of the manuscript. The nine-canon configuration implies a particular directionality of use. The reader begins from a section number in the gospels, then identifies parallels in the canons. This is one way to use the Eusebian apparatus-and, indeed, is how Eusebius himself describes the system in the Letter to Carpianus. Nonetheless, the full Eusebian system could facilitate other modes of access. ${ }^{20} \mathrm{~A}$ user of Eusebius's system who wanted to find the rare uniquely Markan sections, for example, (Eusebius has only nineteen of them) could start with the Markan portion of canon X. Eusebius's system facilitates the reader's access both to specific gospel parallels and to patterns of gospel relationships. In the revised design found in Österreichi-

20 Augustine of Hippo (354-430 CE) employed the Eusebian apparatus to prepare his de consensu evangelistarum. Augustine engaged almost all of Eusebius's parallels, including a number of creative juxtapositions that originate with Eusebius. More significantly, Augustine was able to access a new kind of information through the apparatus. He stated that: 'Mark follows [Matthew] closely [...] in his narrative he gives nothing in harmony with John apart from the others: by himself separately, he has little to record; in conjunction with Luke, as distinguished from the rest, he has still less; but in harmony with Matthew, he has a very large number of passages [...] where the agreement is either with that evangelist alone, or with him in connection with the rest' (1.2.4 [CSEL 43: 4.12-16], author's translation). Such conclusions about the number of parallel passages in different groupings of gospels would be difficult to reach without a full set of gospel canons to enable such comparisons. In the mid-twentieth century, Angelo Penna argued that Augustine did not use the Eusebian apparatus (1955); in arguing that Augustine did use the apparatus, I concur with recent reassessments by Watson 2013, 17-19; Crawford 2019, 125-155, 297-309. 
sche Nationalbibliothek, Suppl. gr. 52, however, one can find uniquely Markan sections only by flipping through the Gospel of Mark and glancing at the marginal canon numbers $(\mathrm{i} / \mathrm{X})$ as one goes. In other words, the Eusebian apparatus in this manuscript has been limited to a particular set of cross-referential reading goals; identifying unique material was (seen as) superfluous. ${ }^{21}$ Such an omission reflects a decision of efficiency based on particular expectations for use.

The thirteenth-century Glasgow, MS Hunter 475 (V.7.2) (GA 560) exemplifies a different kind of omission. ${ }^{22}$ Sections were marked throughout all four gospels, but the canons were listed only for Matthew. As observed by a reader around the turn of the twentieth century, who pencilled their observations into the manuscript itself: 'Matthew has, on the margins, the Ammonian Sections with reference to the Eusebian Canons [...] but the running numbers on the margins of the other gospels are simply those of the Ammonian Sections, and have no reference to the Canon'. ${ }^{23}$ Perhaps the person inserting rubricated canon numbers simply abandoned the task after finishing Matthew. ${ }^{24}$ Since other features are rubricated throughout the gospels, however, it seems more likely that the omission was intended. The omission positions Matthew as the lead gospel for the Eusebian apparatus. One can navigate from Matthew to parallels in other gospels, but there was apparently no need to move in the other direction. The omission suggests an approach to gospel reading that is structured around Matthew. ${ }^{25}$

21 Manuscripts that omitted the main canons in favor of miniature reference tables on each page (as occurs in some Greek, Gothic, Latin, and Syriac manuscripts) likewise made it difficult to access overarching patterns of gospel relationship. On these miniature reference tables, see Gregory 1900, 862-863.

22 While most of the manuscript is from the thirteenth century, the first two quires (which include the canons) are from the fourteenth.

23 This note is pencilled on fol. iv, 6. According to the Hunter Library's online catalogue (http://collections.gla.ac.uk/\#/details/ecatalogue/ 296844; last accessed on 13/04/2020), the note might be attributable to Caspar Gregory or F. H. A. Scrivener.

24 Von Soden 1902, 392-393 identified a number of manuscripts that only partially mark the gospel sections. For a list of manuscripts that number the sections but not the canons, see Gregory 1900, 862. This latter phenomenon suggests that for some readers the canon numbers (and thus the cross-referential function of the Eusebian apparatus) were irrelevant; in such cases, the Eusebian sections retain a referential function even though they no longer direct the reader to parallel passages in other gospels.

25 For a similar omission, see the sixth- or seventh-century Syriac manuscript London, British Library, Add. MS 14445, which has no initial canons and included miniature canons only on the pages of Matthew. This has the effect of facilitating navigation from Matthew to the other three gospels, but not vice versa.
Both examples illuminate how the Eusebian apparatus facilitated access to the gospels. Nonetheless, these omissions are underdetermined. They guide the reader by removing possibilities rather than offering new ones. It is thus instructive to consider other readerly interventions in the Eusebian apparatus.

Other changes imply particular practices of reading in more direct ways. Like omitting a canon that is deemed unnecessary, resequencing a canon while keeping the parallels intact suggests certain readerly priorities. As an example, I return to Paris, Bibliothèque nationale de France, MS grec 230 (GA 12) (see Fig. 2). As I noted above, the parallels in this manuscript were copied accurately; however, a significant modification reflects readers' priorities. Bibliothèque nationale de France, MS grec 230 arranged John in order rather than Luke. Normally, the Eusebian apparatus (including canon IX) organizes sections in the sequence of the first column in each canon; here in Bibliothèque nationale de France, MS grec 230, however, the second column takes over. Table 1 shows the complicated three-by-three block mentioned above in its resulting new arrangement.

Tab. 1: Complex Juxtapositions in Canon IX.

\begin{tabular}{cc}
\hline Luke & John \\
\hline 303 & 182 \\
307 & 182 \\
312 & 182 \\
303 & 186 \\
307 & 186 \\
312 & 186 \\
303 & 190 \\
307 & 190 \\
312 & 190 \\
\hline
\end{tabular}

As with the omissions discussed above, this resequencing implied a particular way of using the apparatus. While such a change may initially seem insignificant, it was not accidental. The revision reflects the directionality of access. Sequencing gospel parallels by John's order rather than Luke's assumes that the reader is working through the Gospel of John and looking up parallels in Luke, rather than the other way around. It thus, moreover, offers evidence for active use of the apparatus.

The Eusebian apparatus facilitates new kinds of textual navigation in other ways, as well-and these sometimes diverge from the original design of the system. The Eusebian sections provided a reference system for lectionary indications. While this was not the original purpose of Eusebius's system of gospel sections and did not 


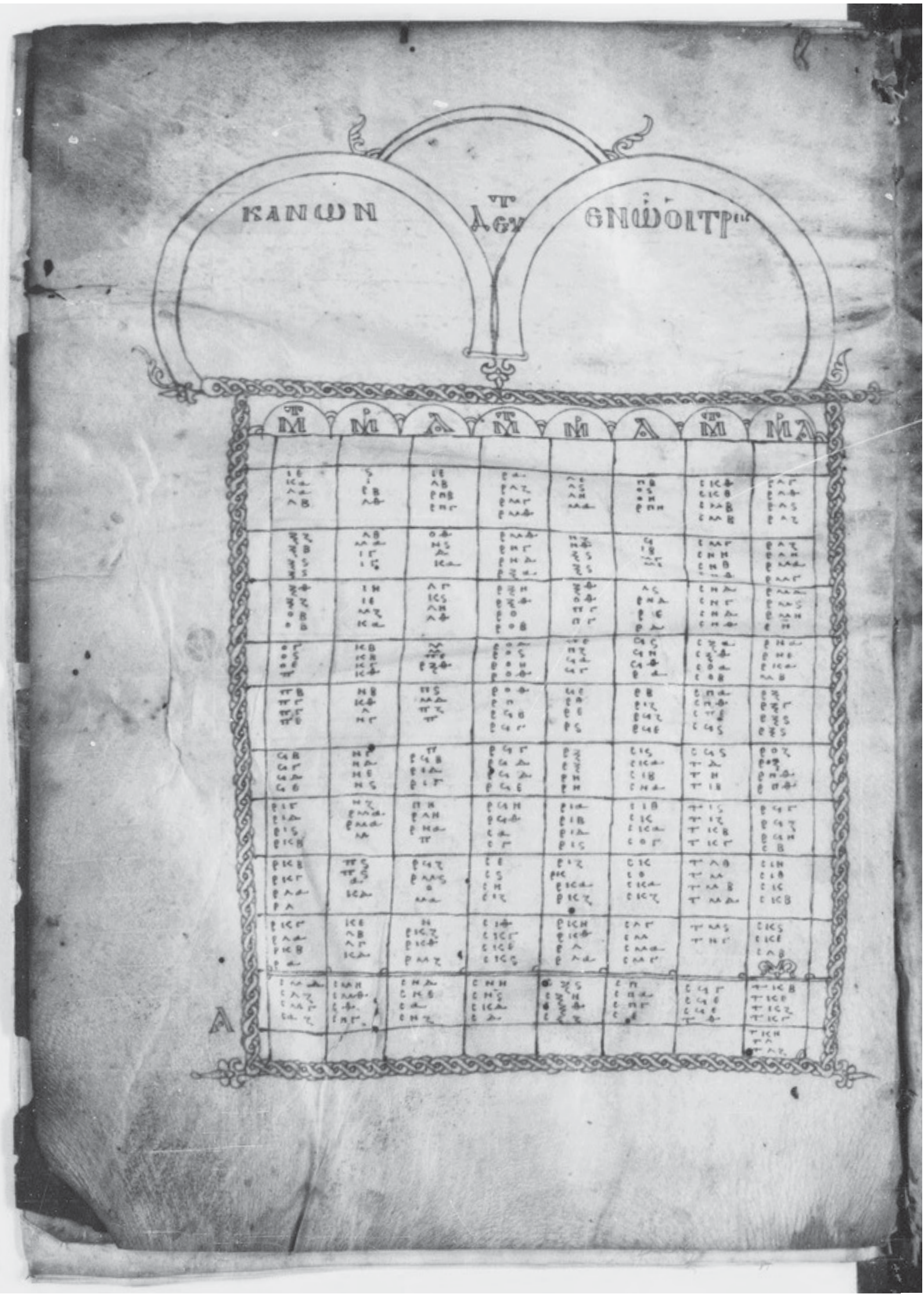

Fig. 3: Paris, Bibliothèque nationale de France, MS grec 177, fols 2v-3r: Canons II, III, and IV. Source gallica.bnf.fr / BnF. 


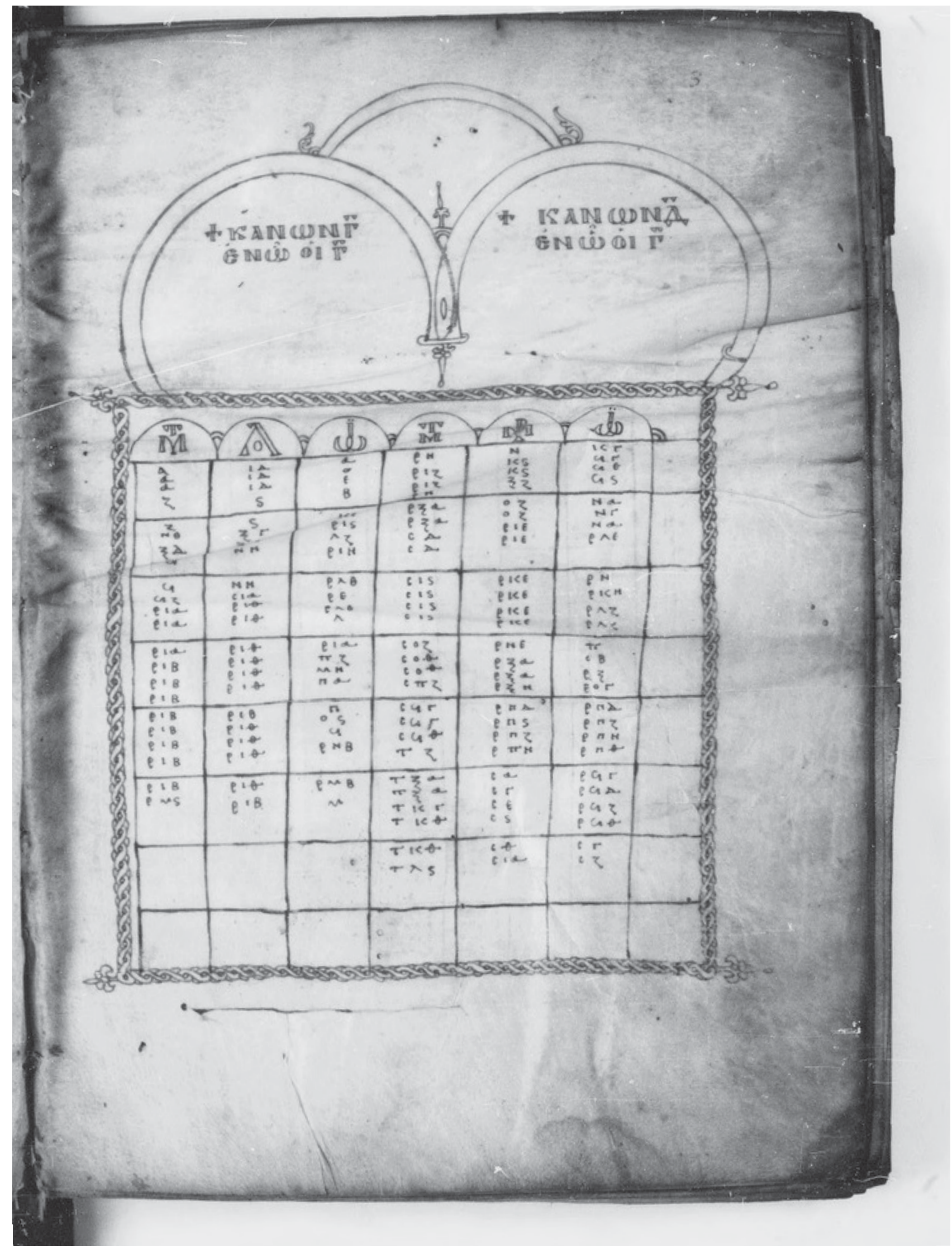




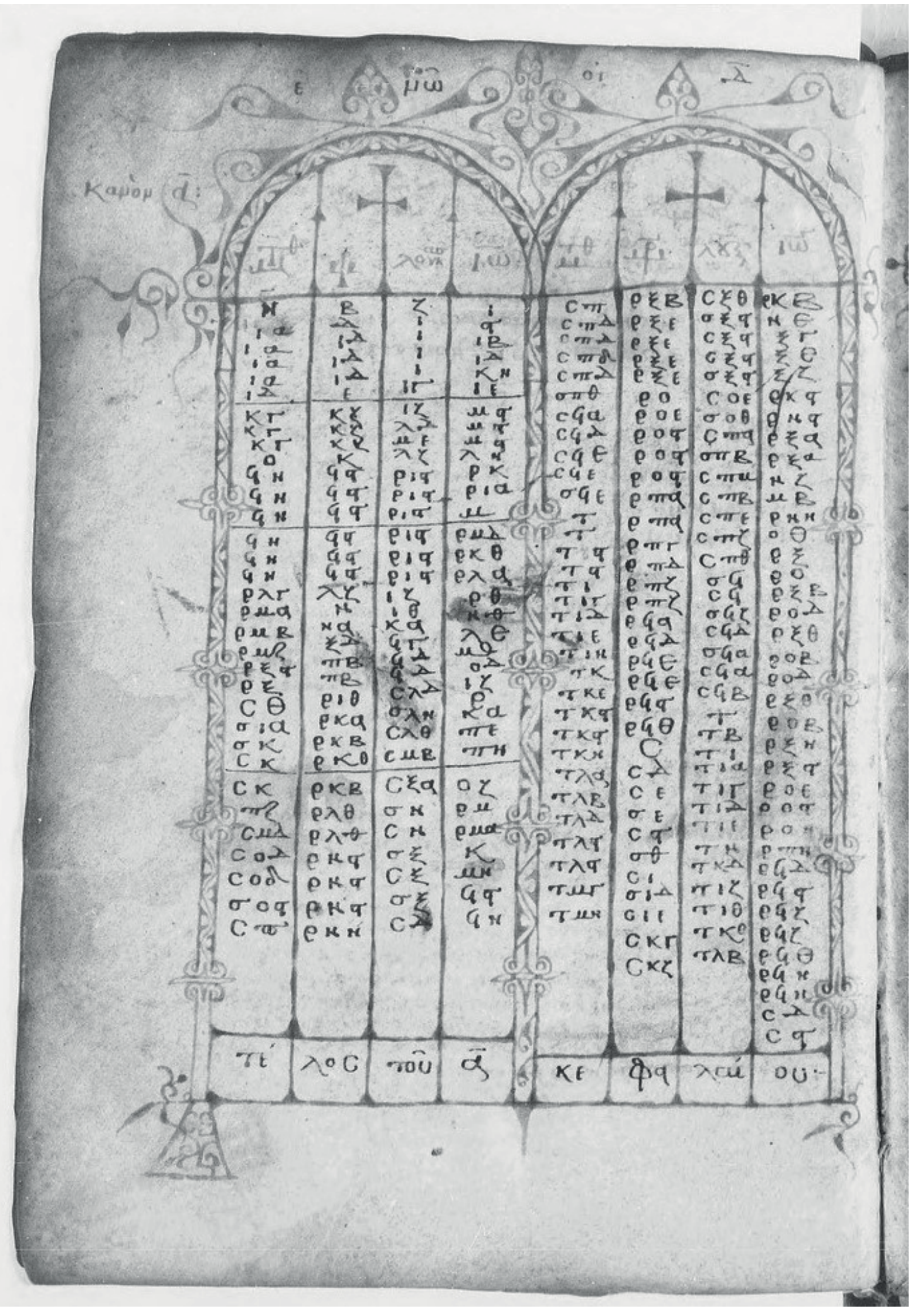

Fig. 4: Paris, Bibliothèque nationale de France, MS grec 79, fols 4v-5r: Canons I and II. Source gallica.bnf.fr / BnF. 


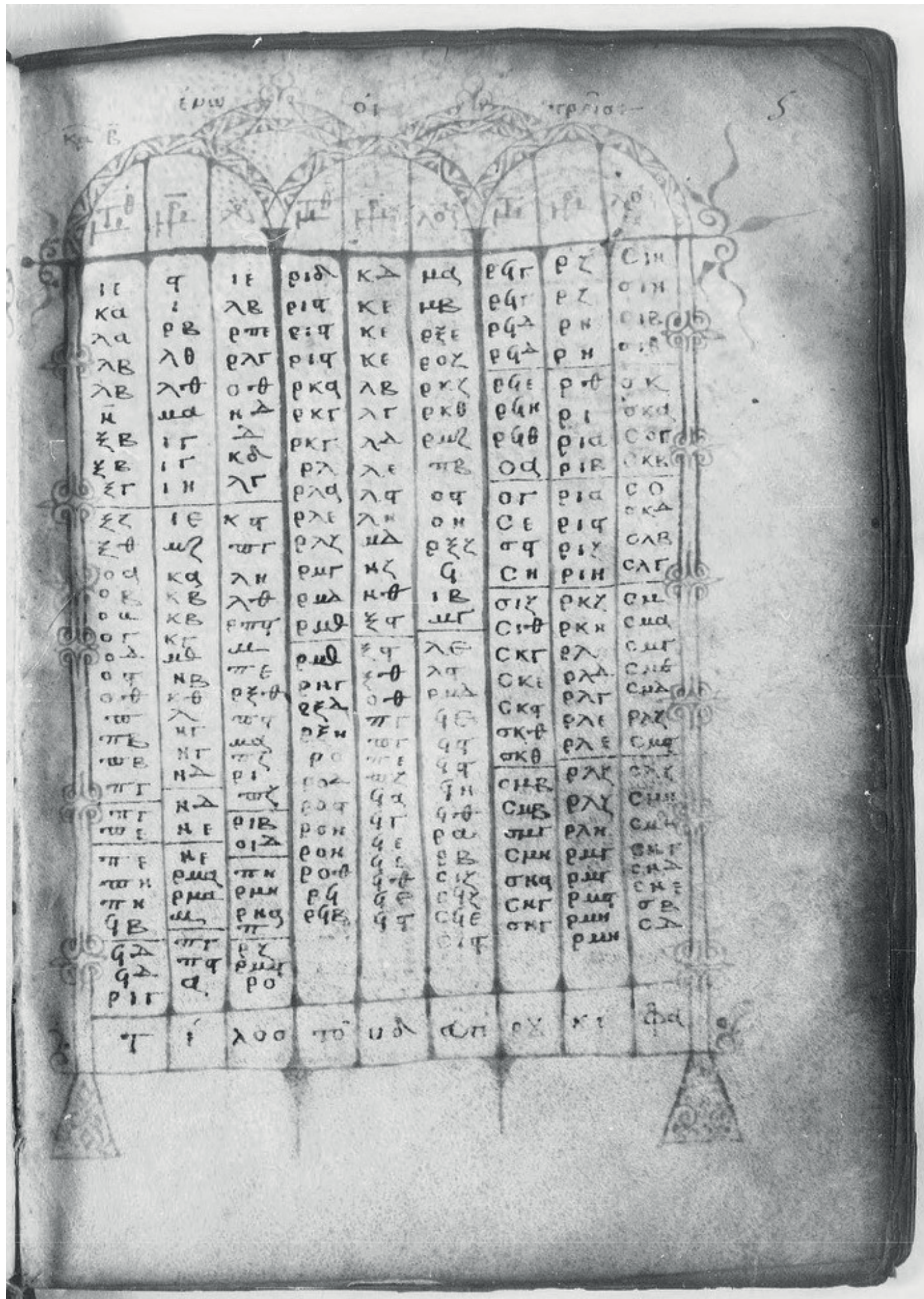




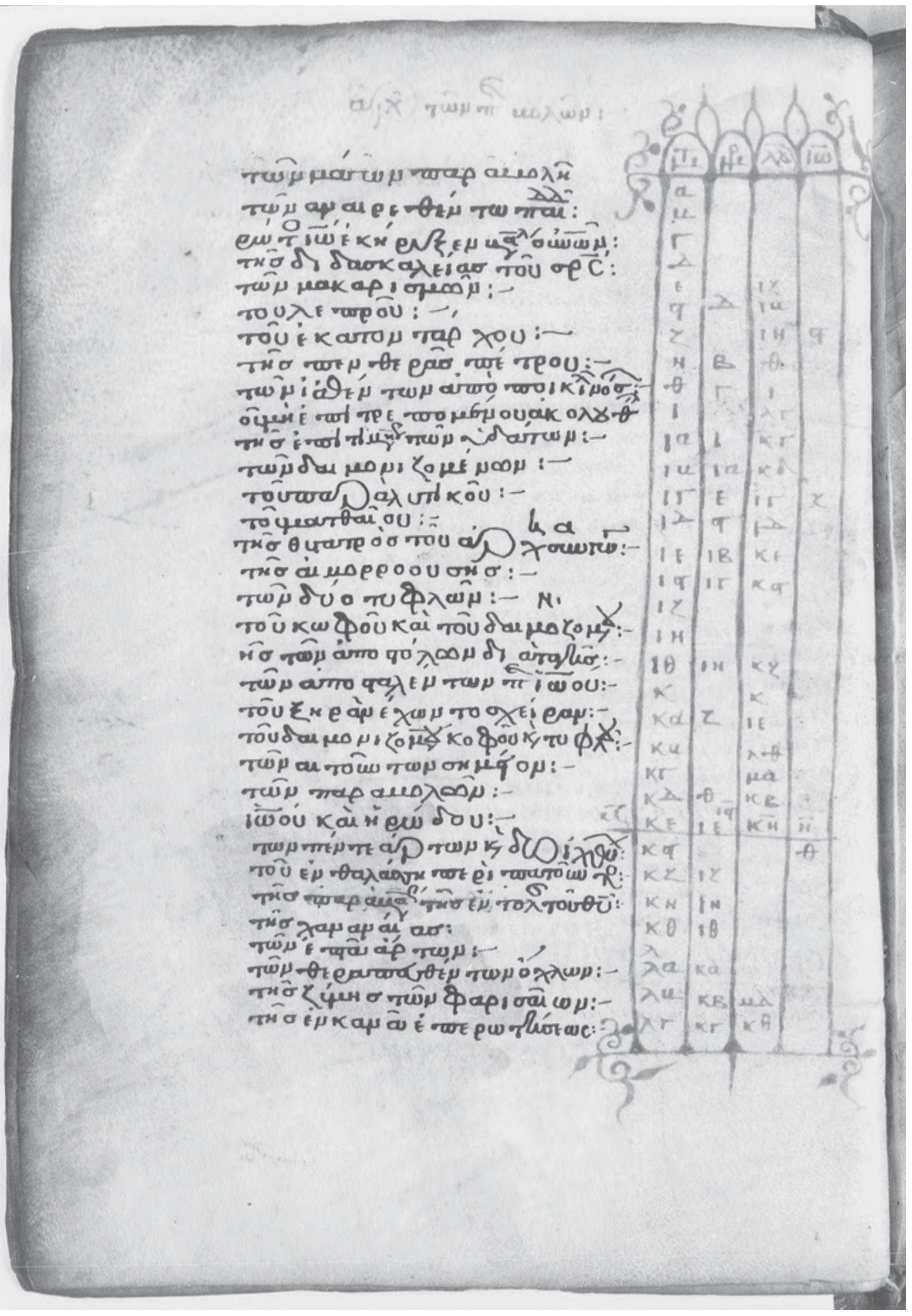

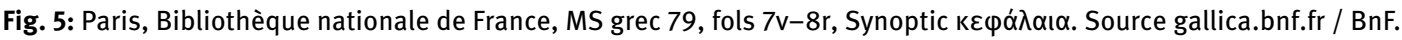




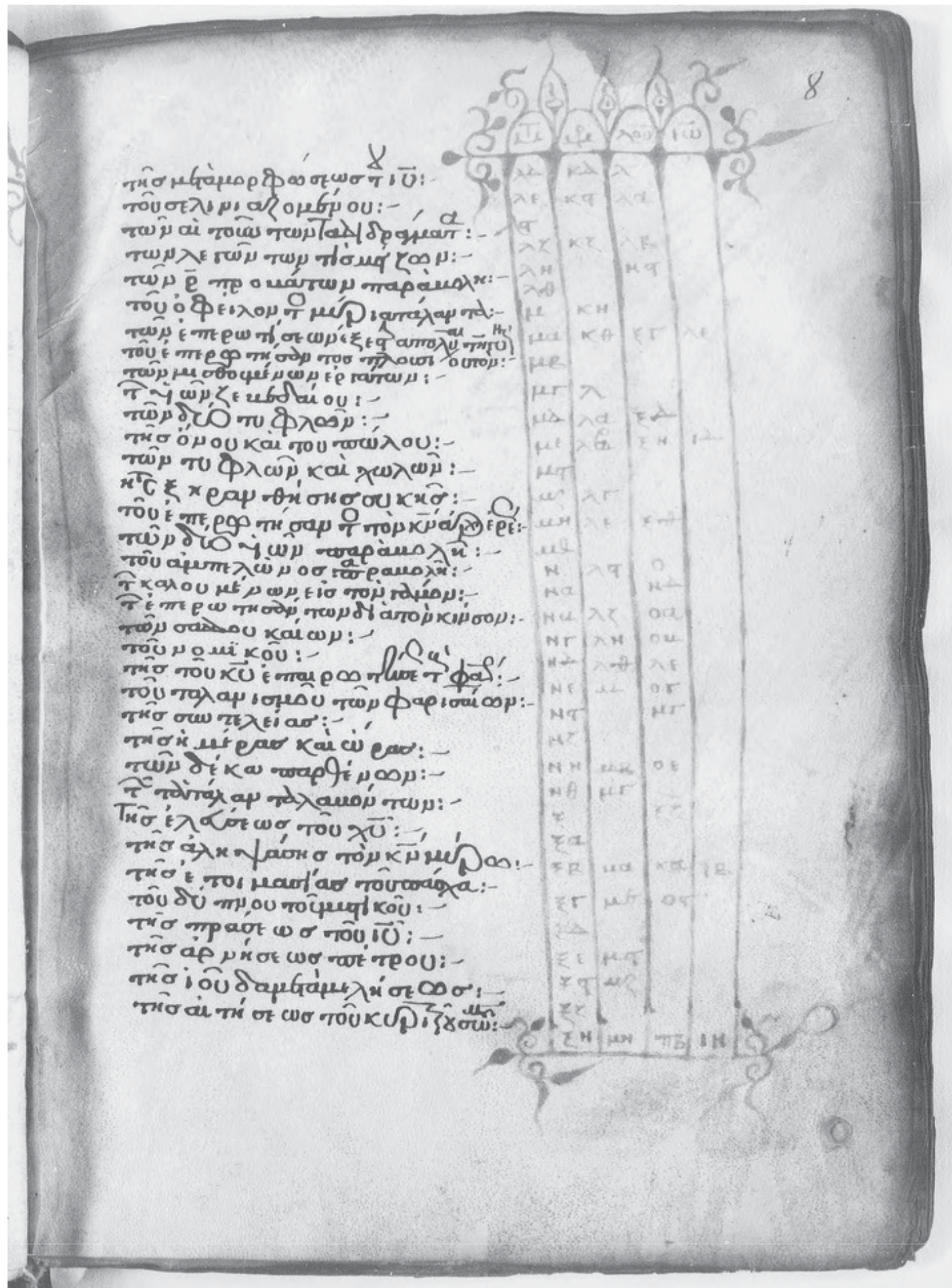


perform any direct cross-referential function, the adaptation is frequently attested in Greek manuscripts. ${ }^{26}$

Furthermore, medieval readers used the Eusebian apparatus to create new paratextual ways of accessing the gospels. In the following paragraphs, I describe a previously understudied example, in which the Eusebian system of parallels is used to align not the Eusebian sections but rather the traditional set of gospel $\kappa \varepsilon \varphi \alpha ́ \lambda \alpha \iota \alpha .{ }^{27}$ To illustrate this phenomenon, I use the thirteenth-century Paris, Bibliothèque nationale de France, MS grec 79 (GA 273). ${ }^{28}$ The manuscript contains a standard set of Eusebian canons (Fig. 4). But it also includes a less common paratext: A gospel table of contents that coordinates the sixty-eight traditional $\kappa \varepsilon \varphi \alpha ́ \lambda \alpha \iota \alpha$ for Matthew with corresponding $\kappa \varepsilon \varphi \alpha ́ \lambda \alpha \_\alpha$ for similar sections in other gospels ${ }^{29}$ (Fig. 5). This, in turn, is followed by a formulaic list that

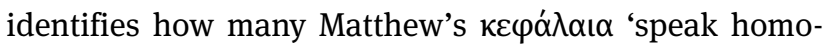

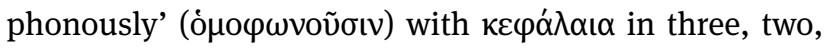
or one other gospels and how many are unique to Matthew alone (Fig. 6).

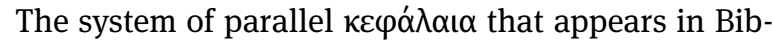
liothèque nationale de France, MS grec 79 depends on the Eusebian apparatus for both its specific juxtapositions

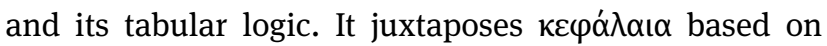
Eusebius's juxtaposition of gospel material. The process used to create the system of parallel $\kappa \varepsilon \varphi \alpha ́ \lambda \alpha \iota \alpha$ can be reconstructed as follows. The starting point was the list

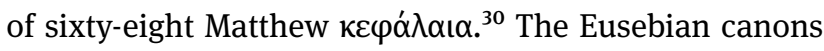

26 For the use of the Eusebian apparatus for lectionary navigation, see Royé 2013; Coogan 2017, 354-55. This use may explain the numerous manuscripts in which Eusebian sections, but not their corresponding canon numbers, are marked.

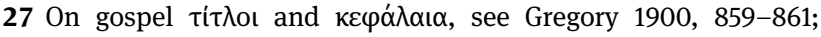
von Soden 1902, 432-435; McArthur 1964; Metzger 1972. On their significance for reading, see Goswell 2009; Edwards 2010; Knust/ Wassermann 2019.

28 A similar arrangement appears in a number of other manuscripts. 29 Readers in Late Antiquity adapted the Eusebian apparatus into a table of contents in various ways. In Greek, the fragmentary Epiphanius canons (New York, Metropolitan Museum of Art inv. (Egyptian) X.455 [LDAB 1062], fourth to seventh century) preserve a handful of notes, located between the columns of the table, that indicate the content of individual sets of parallels. More magnificently, the sixth-century Latin Codex Brixianus (Brescia, Biblioteca civica Queriniana s.n., Manoscritto Purpureo [VL 10]) provides an incipit for each set of Eusebian parallels. The result is a set of canons that expands to fill some one hundred fifty folios, of which some seventy are still preserved. So-called initia canones continue to be an occasional feature in Latin manuscripts with the Eusebian apparatus. Although it exhibits a conceptual similarity with these earlier examples, the system I describe is distinct.

30 As in a number of other modifications of the Eusebian apparatus, here users of the Eusebian apparatus prioritize Matthew. The table

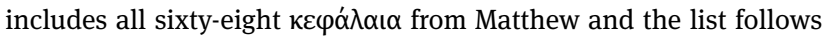

were then used to correlate the Eusebian section corresponding most closely to the beginning of each indivi-

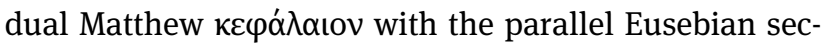
tions-if any exist-in Mark, Luke, and John. ${ }^{31}$ Finally, the $\kappa \varepsilon \varphi \alpha ́ \lambda \alpha \iota \alpha$ from Mark, Luke, and John that most closely correspond to these Eusebian sections are included in the

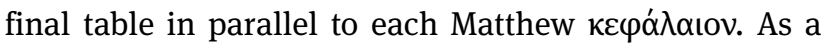
result, Eusebius's decisions about the juxtaposition (and non-juxtaposition) of gospel material are preserved in the $\kappa \varepsilon \varphi \alpha \dot{\lambda} \alpha \iota \alpha$.

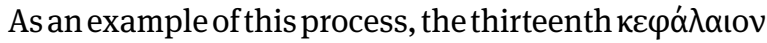

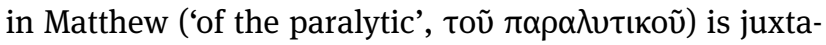
posed with Mark's fifth $\kappa \varepsilon \varphi \alpha$ $\lambda \alpha$ เov, Luke's thirteenth, and John's seventh (fol. 7v). ${ }^{32}$ Table 2 shows how Eusebius's juxtapositions of gospel material correspond to this set of

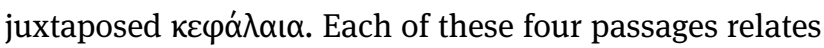
the healing of a paralytic, although the narrative in John diverges in significant ways from the other three.

Tab. 2: Parallel Healings of a Paralytic.

\begin{tabular}{|c|c|c|c|c|}
\hline & Matthew & Mark I & Luke J & John \\
\hline 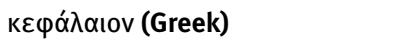 & $\overline{\mathrm{IY}}$ & $\bar{\varepsilon}$ & $\overline{\mathrm{IY}}$ & $\bar{\zeta}$ \\
\hline 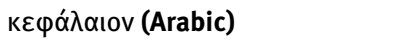 & 13 & 5 & 13 & 7 \\
\hline 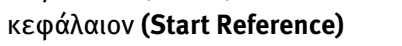 & $9: 2$ & $2: 3$ & $5: 25$ & $5: 5$ \\
\hline $\begin{array}{l}\text { Corresponding Eusebian Section } \\
\text { (Greek) }\end{array}$ & 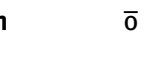 & $\overline{\mathrm{K}}$ & $\overline{\lambda \zeta}$ & $\overline{\lambda \eta}$ \\
\hline $\begin{array}{l}\text { Corresponding Eusebian Section } \\
\text { (Arabic) }\end{array}$ & 70 & 20 & 37 & 38 \\
\hline $\begin{array}{l}\text { Corresponding Eusebian Section } \\
\text { (Start Reference) }\end{array}$ & $9: 1$ & $2: 1$ & $5: 18$ & $5: 1$ \\
\hline
\end{tabular}

Matthew's order; corresponding material from other gospels is included only insofar as it has a parallel in Matthew. Unlike in the ten Eusebian canons, there is no differentiation based on patterns of gospel relationship. The table includes rows in which Matthew is juxtaposed with all three other gospels (corresponding to what Eusebius put into canon I), but it also includes material that is shared with Matthew by only one or two other gospels and material that is uniquely Matthean. There is no place for material found in other gospels but not in Matthew. In its prioritization of Matthew, the system resembles the third-century synopsis designed by Ammonius of Alexandria and discussed by Eusebius in his Letter to Carpianus (see Crawford 2015; Coogan 2017).

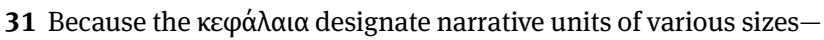
generally larger than Eusebian sections-while the Eusebian sections divide the gospels based on relationships of similarity with other gos-

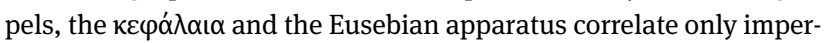
fectly as systems for textual division.

32 In this case, the traditional $\tau i \tau \lambda$ o are the same for all four passages. Given the centrality of Matthew to this cross-referential presentation of $\kappa \varepsilon \varphi \alpha ́ \lambda \alpha \iota \alpha$, it is unsurprising that $\tau i \tau \lambda$ o from Matthew are used even when the parallel $\kappa \varepsilon \varphi \alpha ́ \lambda \alpha \iota \alpha$ are traditionally designated with slightly different $\tau i \tau \lambda o$. 


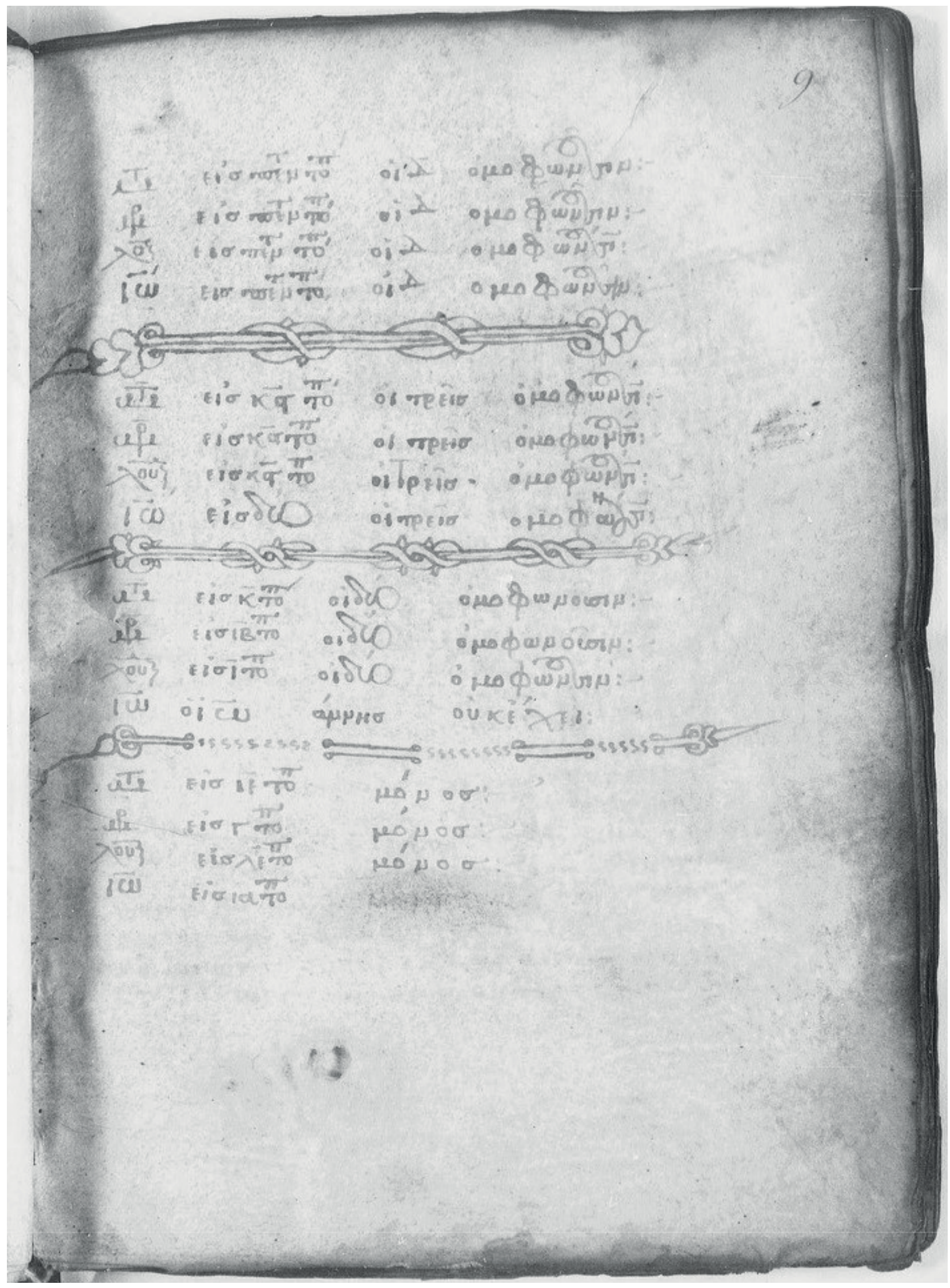

Fig. 6: Paris, Bibliothèque nationale de France, MS grec 79, fol. 9r. Source gallica.bnf.fr / BnF. 
The table of contents also uses the Eusebian appara-

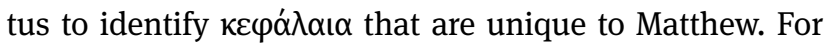
example, in the case of the seventeenth tí $\lambda$ os ('of two

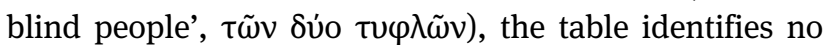

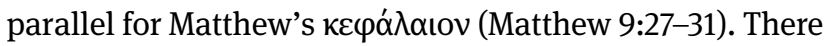

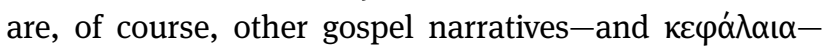
about the healing of the blind (Mark 10:46-52; Luke 18:35-43; John 9:1-41). Nonetheless, this system of parallel

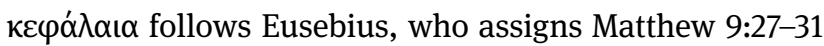
$(=\S 75)$ to canon $\mathrm{X}$ as material without parallel in other gospels and instead juxtaposes the healings in Mark 10 and Luke 18 with the healing of the blind from Matthew 20:29-34..$^{33}$ When Eusebius chose not to link gospel passages, they remain non-aligned in this system of parallel $\kappa \varepsilon \varphi \alpha ́ \lambda \alpha \iota \alpha$. Even though the Eusebian canons and sections

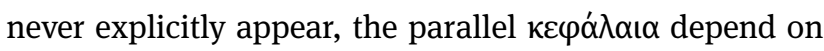
Eusebian juxtapositions of gospel material.

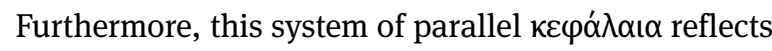
the columnar and synoptic logic of the Eusebian apparatus. The result is a gospel table of contents that, like the Eusebian apparatus itself, articulates gospel similarity and difference. This table of contents juxtaposes paral-

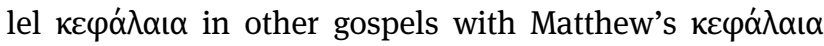
and their $\tau i \tau \lambda$ o. Comparative use seems intended, since the numbers for corresponding $\kappa \varepsilon \varphi \alpha ́ \lambda \alpha \iota \alpha$ in the other gospels are juxtaposed with Matthew's $\kappa \varepsilon \varphi \alpha ́ \lambda \alpha \iota \alpha$. This is made explicit by the following list that identifies

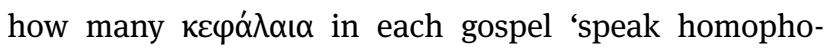

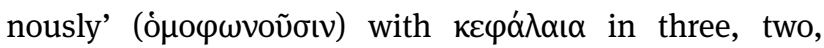
or one other gospels (fol. 9r). The language of 'homophony' (ò $\mu$ $\varphi \omega v o v ̃ \sigma v)$ echoes Eusebius's description of the gospel apparatus in his Letter to Carpianus. ${ }^{34}$ In its layout, too, the comparative table of $\kappa \varepsilon \varphi \alpha ́ \lambda \alpha \iota \alpha$ resembles the iconic arcaded columns used for the Eusebian apparatus in this and many other manuscripts. (Compare fols $4 \mathrm{v}-5 \mathrm{r}$ and fols $7 \mathrm{v}-8 \mathrm{r}$, shown in Figs 4 and 5 above.) This

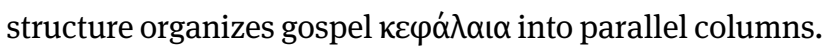
The system found in Bibliothèque nationale de France, MS grec 79 and other manuscripts reflects the ongoing generative power of the Eusebian apparatus. While based on the Eusebian canons, this is no longer an arrangement by canon as such (or even by pattern of gospel relationship). Nonetheless, it illustrates how readers used the Eusebian apparatus to access gospel similarity and difference.

33 Eusebius assigns John's account of Jesus' healing of a blind man (John 9:1-41) to canon X as part of a major block of uniquely Johannine material arranged as a single section (§89, John 8:21-10:14). 34 Eusebius states that the Eusebian apparatus will allow readers to

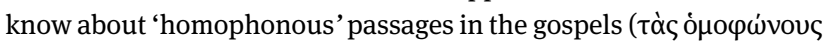

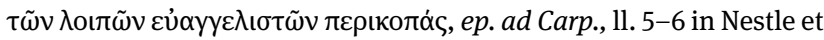
al. 2012, 89^-90^).

\section{Conclusion}

As they approached the gospels, medieval readers continued to employ Eusebius's paratextual apparatus. In so doing, they left their readerly fingerprints in its manuscript history. ${ }^{35}$ By examining the transmission and transformation of the Eusebian apparatus in a number of Greek manuscripts, this study illuminates the Rezeptionsgeschichte of the Eusebian apparatus in two significant ways. First, the Eusebian apparatus remained functional. This challenges the claims of Jülicher and the assumptions of much twentieth-century scholarship on the Eusebian apparatus. Second, the apparatus continued to shape the reading of the gospels. This requires revising historical narratives which imply that interest in comparative gospel reading had disappeared in the Middle Ageseven if perhaps these reading practices looked somewhat different than they had for Eusebius in the fourth century.

One of the best ways to observe the Eusebian apparatus in use, I argue, is to watch it change. The apparatus was a tool for reading the gospels. On the whole, the manuscript tradition does not demonstrate a concern to preserve any 'pristine' original form resembling Eusebius's own text (Theophanes notwithstanding). Seldom did readers care about Eusebius's intentions. Changes to the Eusebian apparatus thus did not always return the system to a more Eusebian form; instead, readers adapted it in order to make it a better resource for their reading of the gospels.

Users modified the Eusebian apparatus in a number of ways, including omission, resequencing, and adaptation for new textual navigation. Each intervention centers on the structure of and access to knowledge, reflecting how readers used the Eusebian system. These varied interventions in the apparatus offer an index for the use of the apparatus and for gospel reading more broadly. Reconfigurations of the Eusebian apparatus, Chartier's 'infinity of singular acts', reflect the changing activities and insights of readers -of different periods and in different places-as they encountered the complexities of the fourfold gospel.

\section{Abbreviations}

CSEL: Corpus Scriptorum Ecclesiasticorum Latinorum GA: Gregory \& Aland reference number, see in references Aland et al. LDAB: Leuven Database of Ancient Books

35 Cf. Kraus 2001. For Kraus, manuscripts are 'Fingerabdrücke einer vergangenen Zeit, die sich im jeweiligen Material, in der spezifischen Schrift bzw. Beschriftung und der Rechtschreibung eines Manuskripts verfestigt haben' (Kraus 2001, 1). 


\section{References}

Aland, Kurt et al. (1994), Kurzgefaste Liste der griechischen Handschriften des Neuen Testaments, Arbeiten zur neutestamentlichen Textforschung, 1, Berlin: De Gruyter.

Baumstark, Anton (1901), 'Syrische Fragmente von Eusebios пврі

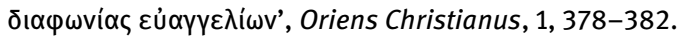

Bausi, Alessandro (2002), 'Some Short Remarks on the Canon Tables in Ethiopic Manuscripts', Studi Magrebini, 26, 45-67.

Bausi, Alessandro (2011), 'The "True Story” of the Abba Gärima Gospels', Comparative Oriental Manuscript Studies Newsletter, 1, 17-20.

Bausi, Alessandro (2015), 'La versione etiopica della Epistola di Eusebio a Carpiano', in Rafał Zarzeczny (ed.), Aethiopia Fortitudo ejus. Studi in onore di Monsignor Osvaldo Raineri in occasione del suo $80^{\circ}$ compleanno, Orientalia Christiana Analecta, 298, Rome: Pontificio Istituto Orientale, 107-135.

Beall, Barbara Apelian (2005), 'Entry Point to the Scriptorium Bede knew at Wearmouth and Jarrow: The Canon Tables of the Codex Amiatinus', Histoire et littérature de l'Europe du Nord-Ouest, 34: 187-197.

Breed, Brennon (2014), Nomadic Text: A Theory of Biblical Reception History, Bloomington: Indiana University Press.

Burgon, John W. (1871), The Last Twelve Verses of the Gospel According to S. Mark Vindicated Against Recent Critical Objectors and Established, Oxford: James Parker.

Butler, Shane, (ed.) (2016), Deep Classics: Rethinking Classical Reception, London: Bloomsbury Academic.

Chartier, Roger (1994), The Order of Books: Readers, Authors, and Libraries in Europe between the Fourteenth and Eighteenth Centuries, Stanford: Stanford University Press.

Coogan, Jeremiah (2017), 'Mapping the Fourfold Gospel: Textual Geography in the Eusebian Apparatus', Journal of Early Christian Studies, 25, 337-357.

Crawford, Matthew R. (2015), 'Ammonius of Alexandria, Eusebius of Caesarea and the Origins of Gospels Scholarship', New Testament Studies, 61, 1-29.

Crawford, Matthew R. (2017), 'Scholarly Practices: The Eusebian Canon Tables in the Hiberno-Latin Tradition', in G.E.M. Gasper, F. Watson, and M.R. Crawford (eds), Producing Christian Culture: Medieval Exegesis and its Interpretive Genres, London: Routledge, 65-88.

Crawford, Matthew R. (2019), The Eusebian Canon Tables: Ordering Textual Knowledge in Late Antiquity, Oxford: Oxford University Press.

de Bruyne, Donatien (1927), 'La préface du Diatessaron latin avant Victor de Capoue’, Revue Bénédictine, 39, 5-11.

Edwards, James R. (2010), 'The Hermeneutical Significance of Chapter Divisions in Ancient Gospel Manuscripts', New Testament Studies, 56, 413-426.

Engelbrecht, Edward A. (1994), 'The Eusebian Canons: An Early Catholic Approach to Gospel Harmony', S.T.M. diss., Concordia Seminary.

Evans, Robert (2014), Reception History, Tradition and Biblical Interpretation: Gadamer and Jauss in Current Practice, London: Bloomsbury.

Goswell, Greg (2009), 'Early Readers of the Gospels: The kephalaia and titloi of Codex Alexandrinus', Journal of Greco-Roman Christianity and Judaism, 6, 134-174.
Grébaut, Sylvain (1913), 'Les dix canons d'Eusèbe et d'Ammonius d'après le ms. éthiopien $\mathrm{n}^{\circ} 3$ de M. E. Delorme', Revue de l'Orient Chrétien, 8, 314-317.

Gregory, Caspar René (1900), Textkritik des Neuen Testaments, Leipzig: Hinrichs.

Gwilliam, George H. (1890), 'The Ammonian Sections, Eusebian Canons, and Harmonizing Tables in the Syriac Tetraevangelium', Studia Biblica et Ecclesiastica, 2, 241-272.

Hall, Isaac H. (1882), 'Notes on the Beirût Syriac Codex', Journal of Biblical Literature, 2, 3-26.

Hardwick, Lorna, and Christopher Stray (eds) (2008), A Companion to Classical Receptions, Malden: Blackwell.

Hixson, Elijah (2019), Scribal Habits in Sixth-Century Greek Purple Codices, Leiden: Brill.

Houghton, H.A.G. (2016), The Latin New Testament: A Guide to its Early History, Texts, and Manuscripts, Oxford: Oxford University Press.

Howlett, David (1996), 'Seven Studies in Seventh-Century Texts', Peritia, 10, 1-70.

Howlett, David (2001), ‘Further Manuscripts of Ailerán's Canon euangeliorum', Peritia, 15, 22-26.

Howlett, David (2010), 'Hiberno-Latin Poems on The Eusebian Canons', Peritia, 21, 162-171.

Hunt, Jeffrey M., R. Alden Smith, and Fabio Stok (2017), Classics from Papyrus to the Internet: An Introduction to Transmission and Reception, Austin: University of Texas Press.

Jauss, Hans Robert (1970), 'Literary History as a Challenge to Literary Theory', New Literary History, 2, 7-37.

Jongkind, Dirk (2007), Scribal Habits of Codex Sinaiticus, Piscataway: Gorgias.

Jülicher, Adolf (1904), An Introduction to the New Testament, London: Smith and Elder.

Kelhoffer, James Anthony (2001), 'The Witness of Eusebius' ad Marinum and Other Christian Writings to Text-Critical Debates concerning the Original Conclusion to Mark's Gospel', Zeitschrift für die Neutestamentliche Wissenschaft, 92, 78-112.

Knust, Jennifer, and Tommy Wasserman (2018), To Cast the First Stone: The Transmission of a Gospel Story, Princeton: Princeton University Press.

Knust, Jennifer, and Tommy Wasserman (2019), 'The Wondrous Gospel of John: Jesus's Miraculous Deeds in Late Ancient Editorial and Scholarly Practice', in Mikael Tellbe, Tommy Wasserman, and Ludvig Nyman (eds), Healing and Exorcism in Second Temple Judaism and Early Judaism, Tübingen: Mohr Siebeck, 160-191.

Kraus, Christina S., and Christopher Stray (eds) (2016), Classical Commentaries: Explorations in a Scholarly Genre, Oxford: Oxford University Press.

Kraus, Thomas J. (2001), 'Ad fontes: Gewinn durch die Konsultation von Originalhandschriften am Beispiel von P.Vindob. G 31974', Biblica, 82, 1-17.

Leroy, Jules (1962), 'Recherches sur la tradition iconographique des canons d'Eusèbe en Éthiopie', Cahiers archéologiques, 12, 173-204.

Mansfeld, Jaap, and David T. Runia (1997), Aëtiana: The Method and Intellectual Context of a Doxographer, Leiden: Brill.

McArthur, Harvey K. (1965), 'The Eusebian Sections and Canons', Catholic Biblical Quarterly, 27, 250-256. 
McArthur, Harvey K. (1964), 'The Earliest Divisions of the Gospels', in Frank L. Cross (ed.), Studia Evangelica, III: Papers Presented to the Second International Congress on New Testament Studies Held at Christ Church, Oxford 1961, II: The New Testament Message, Berlin: Akademie Verlag, 266-272.

McGurk, Patrick (1955), 'Canon Tables in the Book of Lindisfarne and in the Codex Fuldensis of St. Victor of Capua', The Journal of Theological Studies, NS 6, 192-198.

McGurk, Patrick (1993), 'The Disposition of Numbers in the Latin Eusebian Canon Tables', in Roger Gryson (ed.), Philologia Sacra. 1. Altes und Neues Testament. 2. Apokryphen, Kirchenväter, Verschiedenes, Freiburg i.B.: Herder, 242-258.

McKenzie, Judith S., and Francis Watson (2016), The Garima Gospels: Early Illuminated Gospel Books from Ethiopia, Manar al-Athar Monograph, 3, Oxford: Manar al-Athar.

Mercier, Jacques (2000), 'La peinture éthiopienne à l'époque axoumite et au XVIIIle siècle', Comptes rendus des séances de l'Académie des Inscriptions et Belle-Lettres, 35-71.

Metzger, Bruce M. (1972), 'Greek Lectionaries and a Critical Edition of the Greek New Testament', in Kurt Aland (ed.), Die alten Übersetzungen des Neuen Testaments, die Kirchenväterzitate und Lektionare, Berlin: de Gruyter, 479-497.

Mullins, Elizabeth (2001), 'The Insular Reception of the Eusebian Canon Table', PhD diss., University College Cork.

Mullins, Elizabeth (2014), 'The Eusebian Canon Tables' HibernoLatin Exegesis: The Case of Vienna, Österreichische Nationalbibliothek, Lat. 940', Sacris erudiri, 53, 323-343.

Nestle, Eberhard (1908), 'Die eusebianische Evangeliensynopse', Neue Kirchliche Zeitschrift, 19, 40-51, 93-114, 219-232.

Nestle, Eberhard, Erwin Nestle, Barbara Aland, Kurt Aland, H. Strutwolf, Iōan D. Karavidopoulos, Carlo M. Martini, Bruce M. Metzger, and Institut für neutestamentliche Textforschung, (eds) (2012), Novum Testamentum Graece, Stuttgart: Deutsche Bibelgesellschaft.

Neugebauer, Otto (1975), A History of Ancient Mathematical Astronomy, New York: Springer.

Nordenfalk, Carl (1938), Die spätantiken Kanontafeln. Kunstgeschichtliche Studien über die eusebianische Evangelien-Konkordanz in den vier ersten Jahrhunderten ihrer Geschichte, I: Textband; II: Tafelband, Die Bücherornamentik der Spätantike, 1, Göteborg: Oscar Isacsons Boktryckeri A.-B.

Nordenfalk, Carl (1982), 'Canon Tables on Papyrus', Dumbarton Oaks Papers, 36, 29-38.

Nordenfalk, Carl (1984), 'The Eusebian Canon-Tables: Some Textual Problems', The Journal of Theological Studies, NS 35/1, 96-104.

O'Loughlin, Thomas (1999), 'The Eusebian Apparatus in Some Vulgate Gospel Books', Peritia, 13, 1-92.

O'Loughlin, Thomas (2007), 'Division Systems for the Gospels: The Case of the Stowe St John (Dublin, RIA, D.II.3)', Scriptorium, 61, 150-164.

O’Loughlin, Thomas (2009), 'The Biblical Text of the Book of Deer (C.U.L. II.6.32): Evidence for the Remains of a Division System from its Manuscript Ancestry', Scriptorium, 63, 30-57.

O'Loughlin, Thomas (2010), 'Harmonizing the Truth: Eusebius and the Problem of the Four Gospels', Traditio, 65, 1-29.

O'Loughlin, Thomas (2017a), 'Some Hermeneutical Assumptions Latent Within the Gospel Apparatus of Eusebius of Caesarea', Studia Patristica, 95, 51-63.
O’Loughlin, Thomas (2017b), 'The Eusebian Apparatus in the Lindisfarne Gospels: Ailerán's Kanon euangeliorum as a Lens for Its Appreciation', in Richard Gameson (ed.), The Lindisfarne Gospels: New Perspectives, Library of the Written Word, 57, The Manuscript World 9, Leiden, Boston: Brill, 96-111.

Oliver, Harold H. (1959), 'The Epistle of Eusebius to Carpianus: Textual Tradition and Translation', Novum Testamentum, 3, 138-145.

Penna, Angelo (1955), 'Il de consensu Evangelistarum ed i Canoni Eusebiani', Biblica, 36, 1-19.

Petersen, William L. (1994), Tatian's Diatessaron: Its Creation, Dissemination, Significance, and History in Scholarship, Leiden: Brill.

Pusey, Philip Edward, and George Henry Gwilliam (eds) (1901), Tetraeuangelium sanctum juxta simplicem Syrorum versionem ad fidem codicum Massorae, editionum denuo recognitum, Oxford: Clarendon.

Royé, Stefan (2013), 'The Cohesion Between the AmmonianEusebian Apparatus and the Byzantine Liturgical Pericope System in Tetraevangelion Codices: Stages in the Creation, Establishment and Evolution of Byzantine Codex Forms', in Stefan Royé, Klaas Spronk, and Gerhard Rouwhorst (eds), $A$ Catalogue of Byzantine Manuscripts in their Liturgical Context: Challenges and Perspectives, Turnhout: Brepols, 55-116.

Scrivener, Frederick Henry Ambrose (1894), A Plain Introduction to the Criticism of the New Testament for the Use of Biblical Students, Cambridge: Deighton and Bell.

Smith, W. Andrew (2014), A Study of the Gospels in Codex Alexandrinus: Codicology, Palaeography, and Scribal Hands, Leiden: Brill.

Thiele, Walter (1981), 'Beobachtungen zu den eusebianischen Sektionen und Kanones der Evangelien', Zeitschrift für die Neutestamentliche Wissenschaft, 72, 100-111.

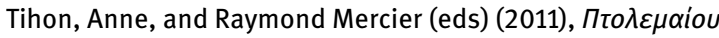

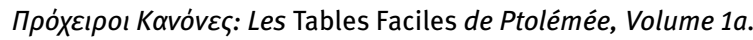
Tables A1-A2. Introduction, Édition critique, Louvain-la-Neuve: Université catholique de Louvain, Institute orientaliste.

Vaccari, Padre Alberto (1957), 'Le sezioni evangeliche di Eusebio e il Diatessaron di Tiziano nella letteratura siriaca', Rivista degli Studi Orientali, 32, 433-452.

von Soden, Hermann Freiherr (1902), Die Schriften des Neuen Testaments in ihrer ältesten erreichbaren Textgestalt hergestellt auf Grund ihrer Textgeschichte, I: Untersuchungen, i: Die Textzeugen, Göttingen: Vandenhoeck und Ruprecht.

Wallraff, Martin (2016), 'Paratexte der Bibel: Was Erasmus edierte außer dem Neuen Testament', in Martin Wallraff, Silvana Seidel Menchi, and Kaspar von Greyerz (eds), Basel 1516: Erasmus' Edition of the New Testament, Tübingen: Mohr Siebeck, 145-174.

Wallraff, Martin, and Patrick Andrist (eds) (2021, forthcoming), Die Kanontafeln des Euseb von Kaisareia: Kritische Edition, Kommentar und Einleitung, Berlin: De Gruyter.

Watson, Francis (2013), Gospel Writing: A Canonical Perspective, Grand Rapids: Eerdmans.

Watson, Francis (2017), 'Lindisfarne and the Gospels: The Art of Interpretation', in Giles E.M. Gasper, Francis Watson, and Matthew R. Crawford (eds), Producing Christian Culture: Medieval Exegesis and its Interpretive Genres, London: Routledge, 47-64.

Zamagni, Claudio (2016), L'extrait des Questions et réponses sur les Evangiles d'Eusèbe de Césarée: Un commentaire, Turnhout: Brepols. 